\title{
The cause of abdominal mass in a child with celiac disease: Rapunzel syndrome. A case report
}

\author{
Yeliz Çağan Appak', Duygu Ertan", Miray Karakoyun"', Gonca Özyurt"v , Tunç Özdemirv', Maşallah Baran" \\ Tepecik Training and Research Hospital, Izmir, Turkey
}

'MD. Attending Physician, Department of Pediatric Gastroenterology, Tepecik Training and Research Hospital, Izmir, Turkey.

(D) https://orcid.org/0000-0002-4330-9281

"MD. Pediatric Assistant, Department of

Pediatrics, Tepecik Training and Research

Hospital, Izmir, Turkey.

(D) https://orcid.org/0000-0002-4804-3048

"'MD. Attending Physician, Department of

Pediatric Gastroenterology, Tepecik Training and Research Hospital, Izmir, Turkey.

(D) https://orcid.org/0000-0002-6533-6256

"MD. Assistant Professor, Department of Child and Adolescent Psychiatry, Tepecik Training and Research Hospital, Izmir Katip Celebi University

School of Medicine, Izmir, Turkey.

(D) https://orcid.org/0000-0002-0508-0594

vMD. Associate Professor, Department of

Pediatric Surgery, Tepecik Training and Research Hospital, Izmir, Turkey.

(D) https://orcid.org/0000-0001-6800-2617

vMD. Associate Professor, Department of

Pediatric Gastroenterology, Tepecik Training and Research Hospital, Izmir Katip Celebi University School of Medicine, İzmir, Turkey

(D) https://orcid.org/0000-0003-3827-2039

\section{KEY WORDS:}

Celiac disease.

Abdomen.

Bezoars.

Trichotillomania.

Depression.

\begin{abstract}
CONTEXT: Rapunzel syndrome is a rare form of gastric trichobezoar that develops through outstretching of the bezoar from the stomach to the intestine.

CASE REPORT: A 12-year-old girl who had been diagnosed with celiac disease six years earlier was brought to the department of pediatric gastroenterology because of abdominal distension. A palpable mass was detected. A trichobezoar that stretched to the small intestine was removed surgically. The patient was diagnosed as having anxiety and depressive disorder, and treatment started. Following the treatment, her previous trichophagia completely disappeared.

CONCLUSION: Presence of trichobezoar should be kept in mind, especially when young girls who have psychiatric problems suffer from gastrointestinal symptoms.
\end{abstract}

\section{INTRODUCTION}

Bezoars are associated with pica, mental retardation and psychiatric disorders among children. ${ }^{1}$ Hair pulling is defined as trichotillomania and eating hair is defined as trichophagia. ${ }^{1}$ The most frequently observed type of bezoar is trichobezoar, which develops in connection with hair deposition. ${ }^{1}$ The mass, which is generally composed of hair, accumulates among the mucosal folds of the stomach and expands over time. Because the rate of expansion is slow, symptoms only appear much later on, in most cases. Ninety percent of bezoars are found in adolescent girls. ${ }^{1}$

Rapunzel syndrome is a rare form of gastric trichobezoar and is formed by elongation of tail-like extensions from a bezoar, along the intestine. Trichophagia and trichotillomania may be observed together with depressive disorders, anxiety disorders and, particularly, obsessive-compulsive disorders. ${ }^{2}$

The case presented here involved presence of a trichobezoar with Rapunzel syndrome in a girl who was being followed up because of a diagnosis of celiac disease.

\section{CASE REPORT}

The patient was a 12-year-old girl, who had been followed up for six years because of a diagnosis of celiac disease. She complained of a condition of painless abdominal distension.

The patient's weight and height were in the normal range according to age. In the physical examination, a mass spreading from the left upper quadrant of the abdomen to the right upper quadrant, passing the middle line, was detected. Other systemic examinations were normal. The laboratory investigation of the case included the following results: white blood cells: 8,900/ul; hemoglobin: $12.4 \mathrm{mg} / \mathrm{dl}$; hematocrit: 38.4\%; thrombocytes: 337,000/ul; iron: $60 \mathrm{ug} /$ $\mathrm{dl}$; iron binding capacity: $250 \mathrm{ug} / \mathrm{dl}$; folic acid: $11 \mathrm{ng} / \mathrm{ml}$; ferritin: $15 \mathrm{ng} / \mathrm{ml}$; and vitamin B12: $216 \mathrm{pg} / \mathrm{ml}$. The results regarding tissue transglutaminase immunoglobulin A (Ig A) (27.58 RU/ $\mathrm{ml}$ ), anti-gliadin immunoglobulin A (IgA) and anti-endomysium antibody IgA were negative.

The patient was fully compliant with her gluten-free diet, according to her own declaration, and did not present any anemia. She showed significantly decreased tissue transglutaminase Ig A, which was $>200 \mathrm{RU} / \mathrm{ml}$ (normal level $<20 \mathrm{RU} / \mathrm{ml}$ ) at the time when celiac disease was initially diagnosed. She was initially positive for anti-gliadin $\operatorname{IgA}$ and anti-endomysium IgA antibodies, at high titers, but she had become negative for these antibodies under her gluten-free diet recently. 
There was no pathological finding from direct abdominal radiography. In the abdominal ultrasonography (USG), the radiologist could not detect any pathological condition. Through computed tomography (CT), most of the stomach could be seen and soft tissue densities that were possibly compatible with a bezoar were observed (Figure 1a, b). Surgical intervention was approved by the department of pediatric surgery. The trichobezoar, which had the shape of the stomach and stretched out towards the small intestine, was removed (Figure 2).

The patient had developed a habit of pulling out and eating her hair over the last year. She was reported to be successful at school, but she suffered from stress during examination periods and her relationships with friends was weak, which meant that she usually spent time on her own. Less hair was noticed in the frontal region of the skull. She underwent evaluation by a child psychiatrist, and this revealed that she was afraid of not being able to grow up adequately because of her celiac disease. Her communication with her peers was weak and she did not want to get involved in the social environment.

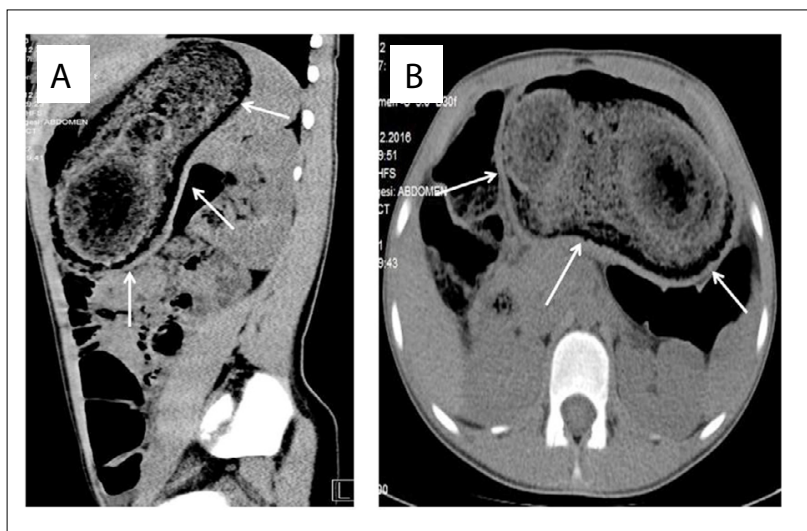

Figure 1. Computed tomography views: soft-tissue densities possibly compatible with a bezoar inside the stomach.

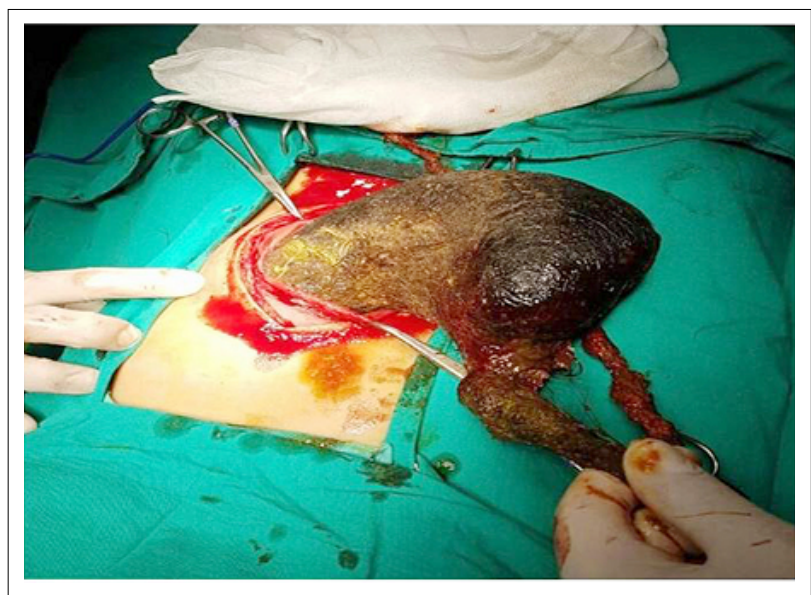

Figure 2. Surgical removal of the trichobezoar that filled the stomach and extended towards the small intestine.
She felt unable to calm herself down and she had initially started to pull out her hair and then started to eat it. The observation made at the end of her psychological assessment was that her anxiety was explicit and that she had depressive complaints. Administration of sertraline $(50 \mathrm{mg} /$ day) was started in connection with anxiety disorder and depressive disorder. During the follow-up at the department of child psychiatry, with cognitive and behavioral techniques therapy, the patient's trichophagia regressed completely. The patient has been followed for the last year since the operation.

\section{DISCUSSION}

Trichophagia and trichotillomania are particularly observed over the first two decades of life, and frequently in girls. ${ }^{1}$ The most frequent findings among children are epigastric mass, epigastric pain, nausea, vomiting, weight loss, diarrhea, constipation and hematemesis. ${ }^{2}$ The diagnosis may be delayed because of the nonspecific symptoms. When the diagnosis is delayed, presence of trichobezoars may lead to serious complications. The most frequent complication is perforation of the stomach and small intestine. Invagination, pancreatitis, intestinal obstruction and peritonitis are infrequent complications. ${ }^{1,2}$

Direct radiography, abdominal USG and/or CT findings can be used in diagnosing trichobezoars. ${ }^{3}$ Upper gastrointestinal system endoscopy has the greatest sensitivity and specificity, given that it can provide information about the structure of the mass. The CT investigation can determine the existence, localization and distribution of the bezoars clearly. ${ }^{3}$ In our case, the bezoar could not be defined by means of USG, but could be viewed using CT.

Methods such as intragastric enzyme application (cellulose, pancreatic lipase, acetylcysteine, etc.), extracorporeal or endoscopic lithotripsy, break-up by means of laser and laparoscopic or open surgery can be used to treat bezoars. Endoscopic treatment is effective for phytobezoars and lactobezoars, since they are small in size and easily breakable, but it has less effect on trichobezoars. Nonetheless, it can be used for small-sized trichobezoars. ${ }^{1}$ Laparoscopic surgery is not advisable because of complications such as difficulty in breaking up the trichobezoar and the risk of obstruction of the intestines due to the broken pieces and deposition of hair in the abdominal cavity. The treatment advised for cases of large trichobezoars consists of the removal of the mass by means of laparotomy. ${ }^{1,2}$

Out of 10 papers in the literature regarding celiac disease, trichotillomania and bezoar (Table 1), only 6 were found to present reports on cases of these three pathological conditions occurring together $^{4-9}$ (Table 2). Trichotillomania and trichophagia may be associated with neuropsychiatric disorders connected with celiac disease. ${ }^{4}$ Additionally, iron deficiency anemia and pica relating to celiac disease may be presented as the reason for presence of trichophagia and bezoars. ${ }^{5}$ Neuropsychiatric disorders and anemia 
secondary to celiac disease were ruled out in this patient's case. Trichotillomania and trichophagia may also be observed together with serious chronic psychiatric disorders such as depressive disorders, anxiety disorders and, particularly, obsessive-compulsive disorders, and together with alcohol and drug addiction. ${ }^{2}$

The reason for trichophagia in our case was associated primarily with the depressive disorder and the anxiety disorder that were detected. Cognitive and behavioral techniques were applied during psychiatric consultations regarding this issue and antidepressant treatment was

Table 1. Articles relating to celiac disease and bezoar that were found through searching the medical literature databases (October 10, 2017)

\begin{tabular}{lccc} 
Database & \multicolumn{1}{c}{ Search strategies } & $\begin{array}{c}\text { Papers } \\
\text { found }\end{array}$ & $\begin{array}{c}\text { Related } \\
\text { papers }\end{array}$ \\
$\begin{array}{lccc}\text { MEDLINE } \\
\text { (via PubMed) }\end{array}$ & $\begin{array}{c}\text { ((celiac disease) OR coeliac disease) AND } \\
\text { ((trichotillomania) OR bezoar) } \\
\text { ("celiac disease"[Mesh]) }\end{array}$ & 1,061 & 10 \\
$\begin{array}{l}\text { LILACS } \\
\text { (via BVS) }\end{array}$ & AND "bezoars"[Mesh] & 818 & 7 \\
\hline
\end{tabular}

Table 2. Case reports on trichotillomania and trichobezoar with celiac disease reported in the literature

\begin{tabular}{|c|c|c|c|}
\hline Author & Publication year & Diagnosis & Treatment \\
\hline $\begin{array}{l}\text { Larsson } \\
\text { et al. }{ }^{4}\end{array}$ & 2004 & $\begin{array}{c}\text { Trichobezoar was } \\
\text { a result of celiac } \\
\text { disease-induced } \\
\text { pica. }\end{array}$ & $\begin{array}{c}\text { Trichobezoar } \\
\text { was removed via } \\
\text { surgery; gluten-free } \\
\text { diet was started. }\end{array}$ \\
\hline $\begin{array}{l}\text { Marcos } \\
\text { Alonso } \\
\text { et al. } .^{5}\end{array}$ & 2005 & $\begin{array}{l}\text { Iron deficiency } \\
\text { anemia and pica } \\
\text { related to celiac } \\
\text { disease. }\end{array}$ & $\begin{array}{l}\text { Trichophagia } \\
\text { regressed through } \\
\text { gluten-free diet. }\end{array}$ \\
\hline $\begin{array}{l}\text { McCallum } \\
\text { et al. }{ }^{6}\end{array}$ & 2008 & $\begin{array}{l}\text { Iron deficiency } \\
\text { anemia and pica } \\
\text { related to celiac } \\
\text { disease. }\end{array}$ & $\begin{array}{l}\text { Trichobezoar } \\
\text { retrieved through } \\
\text { laparotomy; } \\
\text { gluten-free diet was } \\
\text { started. }\end{array}$ \\
\hline $\begin{array}{l}\text { Irastorza } \\
\text { et al. }\end{array}$ & 2014 & $\begin{array}{l}\text { Neuropsychiatric } \\
\text { disorder connected } \\
\text { with celiac disease. }\end{array}$ & $\begin{array}{l}\text { Trichophagia } \\
\text { regressed through } \\
\text { gluten-free diet. }\end{array}$ \\
\hline $\begin{array}{l}\text { Lihabi } \\
\text { et al. }{ }^{8}\end{array}$ & 2016 & $\begin{array}{l}\text { Trichotillomania } \\
\text { was due to } \\
\text { behavioral } \\
\text { disorders secondary } \\
\text { to celiac disease. }\end{array}$ & $\begin{array}{l}\text { Trichotillomania } \\
\text { improved through } \\
\text { gluten-free diet. }\end{array}$ \\
\hline $\begin{array}{l}\text { Kalyoncu } \\
\text { et al. }{ }^{9}\end{array}$ & 2017 & $\begin{array}{l}\text { Trichotillomania } \\
\text { was caused } \\
\text { by behavioral } \\
\text { disorders secondary } \\
\text { to celiac disease. }\end{array}$ & $\begin{array}{l}\text { Trichobezoar was } \\
\text { removed through } \\
\text { surgery; gluten-free } \\
\text { diet continued. }\end{array}$ \\
\hline
\end{tabular}

started. The patient's trichophagia regressed completely through the treatments applied.

\section{CONCLUSION}

Particularly when young girls with psychiatric problems complain of gastrointestinal system symptoms like palpable mass, abdominal pain and vomiting, they should be investigated for any history of trichophagia.

\section{REFERENCES}

1. Eng K, Kay M. Gastrointestinal bezoars: history and current treatment paradigms. Gastroenterol Hepatol (N Y). 2012;8(11):776-8.

2. Frey AS, McKee M, King RA, Martin A. Hair apparent: Rapunzel syndrome. Am J Psychiatry. 2005;162(2):242-8.

3. Ripollés T, García-Aguayo J, Martínez MJ, Gil P. Gastrointestinal bezoars: sonographic and CT characteristics. AJR Am J Roentgenol. 2001;177(1):65-9.

4. Larsson LT, Nivenius K, Wettrell G. Trichobezoar in a child with concomitant coeliac disease: a case report. Acta Paediatr. 2004;93(2):278-80.

5. Marcos Alonso S, Bravo Mata M, Bautista Casasnova A, Pavón Belinchón P, Monasterio Corral L. [Gastric trichobezoar as an atypical form of presentation of celiac disease]. An Pediatr (Barc). 2005;62(6):601-2.

6. McCallum IJ, Van zanten C, Inam IZ, et al. Trichobezoar in a child with undiagnosed coeliac disease. J Paediatr Child Health. 2008;44(9):524-5.

7. Irastorza I,Tutau C, Vitoria JC. A trichobezoar in a child with undiagnosed celiac disease: a case report. World J Gastroenterol. 2014;20(5):1357-60.

8. Lihabi AA. Trichotillomania in Celiac Disease. Case Rep Gastroenterol. 2016;10(3):613-6.

9. Kalyoncu T, Çıldır DA, Özbaran B. Trichotillomania in celiac disease patient refractory to iron replacement. Int J Adolesc Med Health. 2017. [Epub ahead of print].

Sources of funding: None

Conflict of Interest: None

Date of first submission: September 8, 2017

Last received: October 5, 2017

Accepted: October 14, 2017

Address for correspondence:

Yeliz Çağan Appak

TepecikTraining and Research Hospital, Department of Pediatric

Gastroenterology, Yenişehir, Izmir, Turkey, 35110

Tel. +905055985229

E-mail:yelizcagan@yahoo.com 